\title{
The Currency of Knowledge: Education and economic growth in Latin America
}

\author{
Andrew Thomas Bosz and Andrew Anthony Rufatt
}

\begin{abstract}
In the early 1960s, Latin America was on the brink of significant economic growth, with school attainment and income levels well ahead of East Asia. However, by 2000, despite greater financial and political efforts to develop their education system to the standard of fully developed countries, Latin America had already been well surpassed by East Asia. By considering the influence of education and human capital accumulation, this paper endeavours to rationalise the disparities between the economic failures of Latin America by comparison to the economic prosperity of East Asia. Internationally standardised cognitive testing consistently shows Latin America below East Asia, indicating a greater quality of education in East Asia. Moreover, Latin America appears to experience some degree of difficulty in retaining its human capital due to 'brain drain'. As such, whilst the Latin American labour force continues to grow, the average level of education is deteriorating, which in turn adversely affects economic prosperity.
\end{abstract}




\section{INTRODUCTION}

Whilst East Asia basks in the security of its economic prosperity, Latin America continues to experience a general lack of economic growth despite abundant land and natural resources (Birdsall 1999). Education is one of the most influential factors affecting productivity as it directly concerns the quality of knowledge and skills of human capital (Hanushek and Woessmann 2009). Although Latin American governments have committed at least as many resources to increase education as East Asia, accumulation of education has been relatively lax by comparison, serving only to exacerbate economic and social class disparities (Birdsall 1999, p. 2).

In this paper we will compare the failures in Latin American economic growth with the success of East Asian economic development by considering education as the most critical factor of human capital as per the endogenous growth model. First, we shall discuss the foundations of endogenous growth theory and how education can help explain economic growth. Second, we shall consider the differences in education between Latin America and East Asia in an endeavour to isolate the discerning factors that grant the two regions near polar opposite levels of success.

\section{ENDOGENOUS GROWTH}

At its core, endogenous growth theory is comprised of two fundamental ideas. First, the theory considers technological progress as a product of economic activity, and second, that knowledge and technology are characterised by increasing returns, subsequently driving economic growth (Cortright 2011). As such, a lack of technological progress would ultimately result in a lack of economic growth.

The simplest expression of growth theory illustrates how domestic output is generated from a given stock of factors (Aghion \& Durlauf 2009). Thus, consider the formula:

$$
Y=A * F(K, L)
$$

In the above formula, $K$ is capital, $L$ is labour, $A$ is the productivity factor reflecting existing knowledge and resulting output efficiency of capital and labour, whilst $F$ is the growth function that is usually assumed to exhibit constant returns to scale (Aghion \& Durlauf 2009, 
p. 8). There are several ways to rewrite the formula, however, the purpose of endogenous growth theory is essentially to explain the growth of $A$ as a direct result of innovation, thus demonstrating productivity growth.

\section{EDUCATION AND HUMAN CAPITAL}

Considering that labour is an important input into economic growth, it stands to reason that education is important as it comprises the knowledge base of labour. Theoretical models of endogenous growth emphasise the importance of education as a production factor that may be accumulated, increasing the innovative capacity of the economy (Hanushek \& Woessmann 2009).

Recent academic literature regarding nation-wide growth regressions and the impact of education rely largely on internationally comparable statistics on average years of schooling as a proxy for the human capital of a particular economy (Barro \& Lee 2001). This method has typically identified a significant positive association between quantitative measures of education and economic growth (Krueger \& Lindahl 2001). However, whilst reliance on the average years of schooling may seem a suitable universal gauge, it implicitly assumes a year of education conveys the same level of knowledge and skills across all education systems and that variation in the quality of non-school factors have only a negligible effect on educational outcomes (Hanushek \& Woessmann 2009, p. 4). For instance, a year of education in Colombia is assumed to increase human capital as much as it would in Singapore.

A more appropriate measure of identifying causal disparities of education between economic regions would be to concentrate on cognitive skills (Hanushek \& Woessmann 2009, p. 5). In a recent review, growth models estimated with data from across the world attribute low cognitive abilities as the reason for lacklustre economic growth in Latin America (Hanushek \& Woessmann 2009).

Figure 1 reveals that whilst total gross domestic product (GDP) is greater in East Asia, when divided by resident populations, GDP per capita is greater in Latin America. This indicates that East Asia possesses a larger human capital base, which in itself is highly beneficial to output. However, despite Latin America's higher GDP per capita, East Asia has a higher 
GDP per capita growth rate. If these trends continue, East Asia will eventually overtake Latin America in terms of GDP per capita - albeit this could take a decade or more.

Figure 1: Comparison of Gross Domestic Product between Latin America and East Asia*

\begin{tabular}{lcccccccccccc}
\hline & \multicolumn{4}{c}{$\begin{array}{c}\text { GDP } \\
\end{array}$} & $\mathbf{2 0 0 7}$ & \multicolumn{4}{c}{ GDP per capita } & \multicolumn{4}{c}{ GDP per capita growth } \\
& $\mathbf{2 0 0 7}$ & $\mathbf{2 0 0 8}$ & $\mathbf{2 0 0 9}$ & $\mathbf{2 0 1 0}$ & $\mathbf{2 0 0 7}$ & $\mathbf{2 0 0 8}$ & $\mathbf{2 0 0 9}$ & $\mathbf{2 0 1 0}$ & $\mathbf{2 0 0 7}$ & $\mathbf{2 0 0 8}$ & $\mathbf{2 0 0 9}$ & $\mathbf{2 0 1 0}$ \\
\hline \hline World & 55,805 & 61,259 & 58,078 & 63,044 & 8,442 & 9,161 & 8,587 & 9,216 & 2.74 & 0.33 & -3.16 & 3.05 \\
\hline $\begin{array}{l}\text { East Asia \& } \\
\text { Pacific }\end{array}$ & 11,878 & 13,679 & 14,088 & 16,219 & 5,503 & 6,295 & 6,441 & 7,367 & 5.07 & 1.74 & -1.26 & 6.38 \\
\hline $\begin{array}{l}\text { Latin America } \\
\text { \& Caribbean }\end{array}$ & 3,878 & 4,518 & 4,194 & 5,182 & 6,811 & 7,845 & 7,200 & 8,798 & 4.64 & 3.16 & -2.91 & 5.01 \\
\hline \hline
\end{tabular}

*Based on World Bank 2011a; 2011b; 2011c

\section{LATIN AMERICA VERSUS EAST ASIA}

In 2000, the Organisation for Economic Co-operation and Development (OECD) started its Programme for International Student Assessment (PISA), testing the cognitive skills of 15year-old students in the areas of literacy, mathematics and science every three years (OECD 2010b). The most recent PISA testing was conducted in 2009, with 65 countries participating.

Figure 2 illustrates the scholastic performance of participating Latin American and East Asian countries for the 2000, 2003, 2006 and 2009 PISA tests. It is evident from the data that the performance of Latin American countries is significantly below the OECD average, whilst East Asian countries are consistently scoring above the OECD average. Thus, the average cognitive skills of Latin American students are consistently at the lower end of the international distribution. Regions above the OECD average increase labour productivity by two per cent for each per cent above the OECD average attained (Coulombe, Tremblay \& Marchand 2004, p. 31). 
Figure 2: Comparing PISA Results between Participating Latin American and East Asian Countries*

\begin{tabular}{|c|c|c|c|c|c|c|c|c|c|c|c|c|c|}
\hline & \multicolumn{4}{|c|}{ Reading Scale } & \multicolumn{5}{|c|}{ Maths Scale } & \multicolumn{4}{|c|}{ Science Scale } \\
\hline & 2000 & 2003 & 2006 & 2009 & & 2000 & 2003 & 2006 & 2009 & 2000 & 2003 & 2006 & 2009 \\
\hline OECD Average & 500 & 494 & 492 & 493 & & 500 & 500 & 498 & 496 & 500 & 500 & 500 & 501 \\
\hline Shanghai - China & - & - & - & 556 & & - & - & - & 600 & - & - & - & 575 \\
\hline Korea & 525 & 534 & 556 & 539 & & 547 & 542 & 547 & 546 & 552 & 538 & 522 & 538 \\
\hline Hong Kong - China & 525 & 510 & 536 & 533 & & 560 & 550 & 547 & 555 & 541 & 548 & 542 & 549 \\
\hline Japan & 522 & 498 & 498 & 520 & & 557 & 534 & 523 & 529 & 550 & 539 & 531 & 539 \\
\hline Chinese Taipei & - & - & 496 & 495 & & - & - & 549 & 543 & - & - & 532 & 520 \\
\hline Macao - China & - & 498 & 492 & 487 & & - & 527 & 525 & 525 & - & 525 & 511 & 511 \\
\hline Chile & 410 & - & 442 & 449 & & 384 & - & 411 & 421 & 415 & - & 438 & 447 \\
\hline Uruguay & - & 434 & 413 & 426 & & - & 422 & 427 & 427 & - & 438 & 428 & 427 \\
\hline Mexico & 422 & 400 & 410 & 425 & & 387 & 385 & 406 & 419 & 422 & 405 & 410 & 416 \\
\hline Colombia & - & - & 385 & 413 & 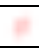 & - & - & 370 & 381 & - & - & 388 & 402 \\
\hline Brazil & 396 & 403 & 393 & 412 & & 334 & 356 & 370 & 386 & 375 & 390 & 390 & 405 \\
\hline Argentina & 418 & - & 374 & 398 & & 388 & - & 381 & 388 & 396 & - & 391 & 401 \\
\hline Panama & - & - & - & 371 & & - & - & - & 360 & - & - & - & 376 \\
\hline Peru & 327 & - & - & 370 & 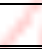 & 292 & - & - & 365 & 333 & - & - & 369 \\
\hline
\end{tabular}

\begin{tabular}{lll}
\hline Significantly above OECD average & Not significantly different OECD average & Significantly below OECD average
\end{tabular}

*Based on OECD 2003; 2004; 2007; $2010 b$

Further to primary and secondary education, the calibre and output of tertiary education in Latin America has also deteriorated in comparison to East Asia. A recent review of the world's top 200 universities by research output identified 27 East Asian universities, whilst Latin America was unrepresented due to tertiary underfunding and stifling governance structures (Baty 2010).

To further appreciate the contrast between Latin America and East Asia we can consider both the output of citable documents and the Hirsh index - a common gauge of the relative quality of published works. The combination of a poor Hirsch index in average terms, and the small volume of published research indicate both quality and quantity of research in Latin America is inferior to that of several East Asian nations. 
Figure 3: Hirsch Index and Research Document Output for 2010 in East Asia and Latin America*

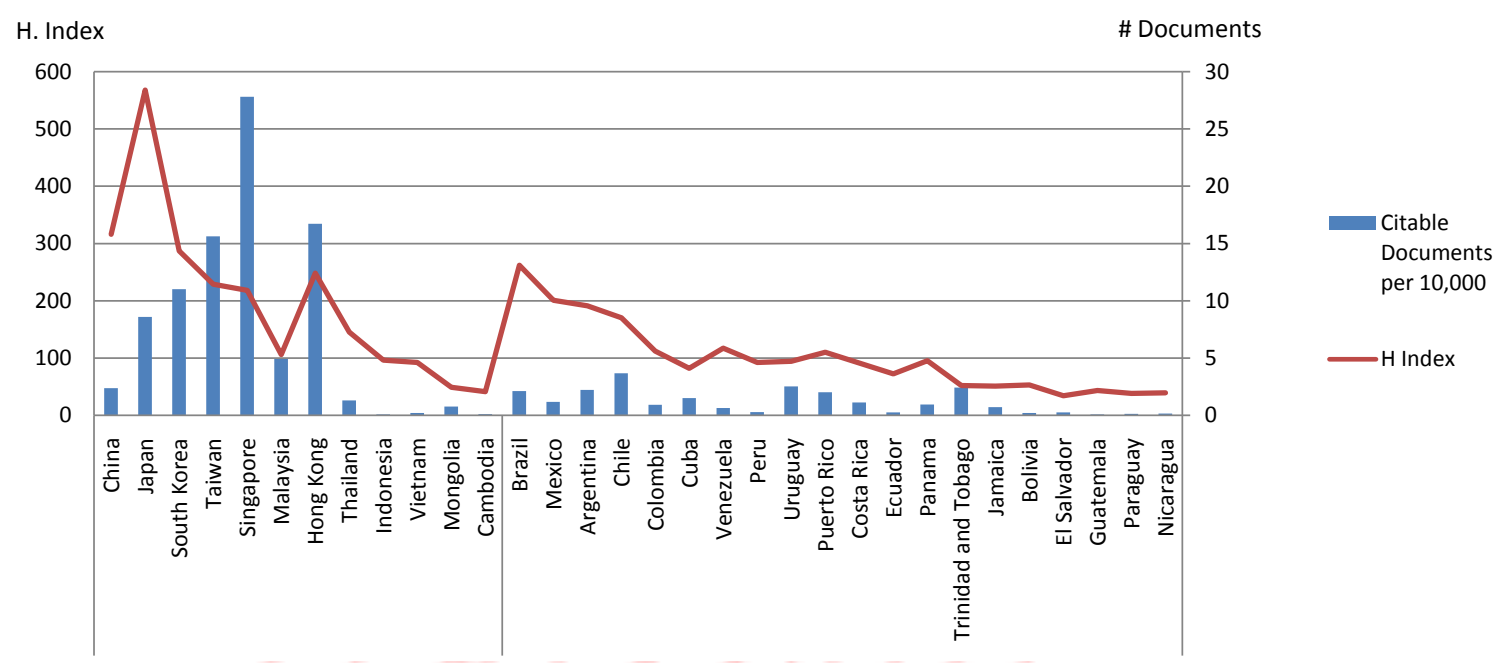

*Based on CIA 2011 and SCImago 2007

Figure 3 shows that East Asia has surged in its output of citable documents per capita whilst published research in Latin America is rather negligible. This difference becomes even more apparent in a trend comparison over time, as demonstrated in Figure 4.

This exponentially broadening handicap in the quality of education could be correlated to the abatement of Latin American economic growth. The materiality of influence on growth attributed to the quality of education is generally undisputed, although quality is argued to be more significant towards economic growth than years of education (Hanushek \& Kimko 2000). 
Figure 4: Citable Document Trend between Latin America and the Asiatic Region*

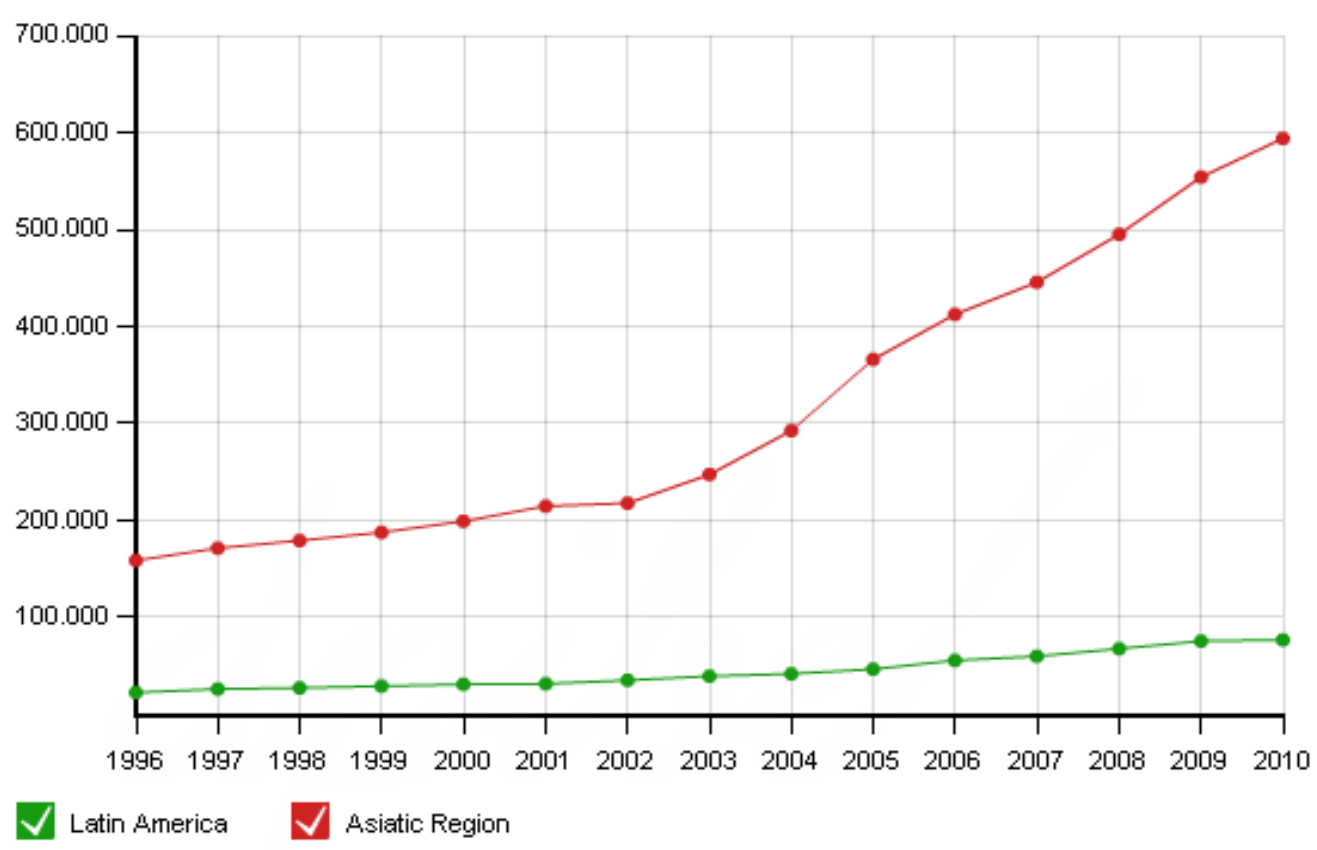

*Source: SCImago 2007

\section{PUBLIC EXPENDITURE ON EDUCATION}

Consideration must be made not only towards development in human capital, but also its retention and accumulation. Interestingly, national expenditure on public education as a percentage of GDP remains relatively comparable between Latin America and East Asia - as demonstrated in Figure 5. Public expenditure measured in this context is indicative of the national commitment to allocate resources towards education (OECD 2010a, p. 1). As such, the disparity is not due to a lack of government willingness to commit public funds. 
Figure 5: Public Expenditure on Education as a Percentage of GDP*

\begin{tabular}{|c|c|c|c|c|c|c|c|c|c|c|c|c|}
\hline Region & Country & 1999 & 2000 & 2001 & 2002 & 2003 & 2004 & 2005 & 2006 & 2007 & 2008 & 2009 \\
\hline \multirow[t]{8}{*}{ East Asia } & Arithmetic average & $3.7 \%$ & $4.4 \%$ & $4.2 \%$ & $4.5 \%$ & $4.6 \%$ & $4.2 \%$ & $4.4 \%$ & $3.7 \%$ & $3.6 \%$ & $3.1 \%$ & $3.8 \%$ \\
\hline & China & $1.9 \%$ & - & - & - & - & - & - & - & - & - & - \\
\hline & Hong Kong & - & - & $3.9 \%$ & $4.0 \%$ & $4.3 \%$ & $4.6 \%$ & $4.2 \%$ & $3.9 \%$ & $3.5 \%$ & $3.3 \%$ & $4.5 \%$ \\
\hline & Japan & $3.6 \%$ & $3.7 \%$ & $3.6 \%$ & $3.6 \%$ & $3.7 \%$ & $3.7 \%$ & $3.5 \%$ & $3.5 \%$ & $3.5 \%$ & - & - \\
\hline & Macao & $3.7 \%$ & $3.7 \%$ & $3.0 \%$ & $3.1 \%$ & $2.9 \%$ & $2.3 \%$ & $2.4 \%$ & $2.3 \%$ & $2.0 \%$ & $2.2 \%$ & - \\
\hline & Malaysia & $5.7 \%$ & $6.0 \%$ & $7.5 \%$ & $7.7 \%$ & $7.5 \%$ & $5.9 \%$ & $7.5 \%$ & $4.7 \%$ & $4.5 \%$ & $4.1 \%$ & - \\
\hline & Republic of Korea & $3.8 \%$ & - & $4.1 \%$ & $4.0 \%$ & $4.4 \%$ & $4.4 \%$ & $4.1 \%$ & $4.2 \%$ & $4.2 \%$ & - & - \\
\hline & Singapore & - & - & $3.1 \%$ & - & - & - & - & - & - & $2.6 \%$ & $3.0 \%$ \\
\hline \multirow[t]{19}{*}{ LATAM } & Arithmetic average & $4.1 \%$ & $4.0 \%$ & $4.0 \%$ & $4.2 \%$ & $4.3 \%$ & $4.3 \%$ & $3.6 \%$ & $4.0 \%$ & $4.5 \%$ & $5.3 \%$ & $3.8 \%$ \\
\hline & Antigua and Barbuda & $3.2 \%$ & - & - & $3.9 \%$ & - & - & - & - & - & - & $2.7 \%$ \\
\hline & Argentina & $4.5 \%$ & $4.6 \%$ & $4.8 \%$ & $4.0 \%$ & $3.5 \%$ & $3.8 \%$ & - & $4.5 \%$ & $4.9 \%$ & - & - \\
\hline & Bolivia & $5.7 \%$ & $5.5 \%$ & $5.9 \%$ & $6.2 \%$ & $6.4 \%$ & - & - & $6.3 \%$ & - & - & - \\
\hline & Brazil & $3.9 \%$ & $4.0 \%$ & $3.9 \%$ & $3.8 \%$ & - & $4.0 \%$ & $4.5 \%$ & $5.0 \%$ & $5.1 \%$ & - & - \\
\hline & Chile & $3.8 \%$ & $3.9 \%$ & - & $4.2 \%$ & $4.1 \%$ & $3.7 \%$ & $3.4 \%$ & $3.2 \%$ & $3.4 \%$ & $4.0 \%$ & - \\
\hline & Colombia & $4.4 \%$ & $3.7 \%$ & $3.9 \%$ & $4.5 \%$ & $4.5 \%$ & $4.2 \%$ & $4.0 \%$ & $3.9 \%$ & $4.1 \%$ & $3.9 \%$ & $4.8 \%$ \\
\hline & Cuba & $7.5 \%$ & $7.2 \%$ & $7.8 \%$ & $8.9 \%$ & $9.2 \%$ & $9.6 \%$ & - & - & $11.9 \%$ & $13.6 \%$ & - \\
\hline & Dominican Republic & - & $1.9 \%$ & $2.0 \%$ & $2.0 \%$ & $1.9 \%$ & - & - & - & $2.2 \%$ & - & - \\
\hline & Ecuador & $1.8 \%$ & $1.3 \%$ & $1.0 \%$ & - & - & - & - & - & - & - & - \\
\hline & El Salvador & $2.3 \%$ & $2.5 \%$ & $2.5 \%$ & $2.9 \%$ & $2.8 \%$ & - & $2.7 \%$ & $3.0 \%$ & $3.0 \%$ & $3.6 \%$ & - \\
\hline & Grenada & - & - & - & - & $4.9 \%$ & - & - & - & - & - & - \\
\hline & Mexico & $4.4 \%$ & $4.9 \%$ & $5.2 \%$ & $5.3 \%$ & $5.3 \%$ & $4.9 \%$ & $5.0 \%$ & $4.8 \%$ & $4.8 \%$ & - & - \\
\hline & Nicaragua & $3.8 \%$ & $3.9 \%$ & - & $3.1 \%$ & $3.1 \%$ & - & - & - & - & - & - \\
\hline & Panama & $4.8 \%$ & $5.0 \%$ & $4.3 \%$ & $4.4 \%$ & $4.4 \%$ & $3.8 \%$ & - & - & - & $3.8 \%$ & - \\
\hline & Paraguay & $5.1 \%$ & $5.3 \%$ & $5.1 \%$ & $4.9 \%$ & $4.7 \%$ & $4.0 \%$ & - & - & $4.0 \%$ & - & - \\
\hline & Peru & $3.4 \%$ & - & $2.9 \%$ & $3.0 \%$ & $2.8 \%$ & $2.8 \%$ & $2.7 \%$ & $2.5 \%$ & $2.5 \%$ & $2.7 \%$ & - \\
\hline & Uruguay & $2.4 \%$ & $2.4 \%$ & $2.8 \%$ & $2.3 \%$ & $2.1 \%$ & $2.5 \%$ & $2.7 \%$ & $2.8 \%$ & - & - & - \\
\hline & Venezuela & - & - & - & - & - & - & - & $3.7 \%$ & $3.7 \%$ & - & - \\
\hline
\end{tabular}




\section{HUMAN CAPITAL FLIGHT}

To appreciate the impact of Latin American emigration on human capital we must understand both the volume and composition of the migrant population. The net migration rates in Figure 6 put into perspective the significant difference between the volumes of the two regions. East Asia's net negative migration rate is materially lower than that of Latin America. Under the growth model, a net emigration rate erodes human capital accumulation.

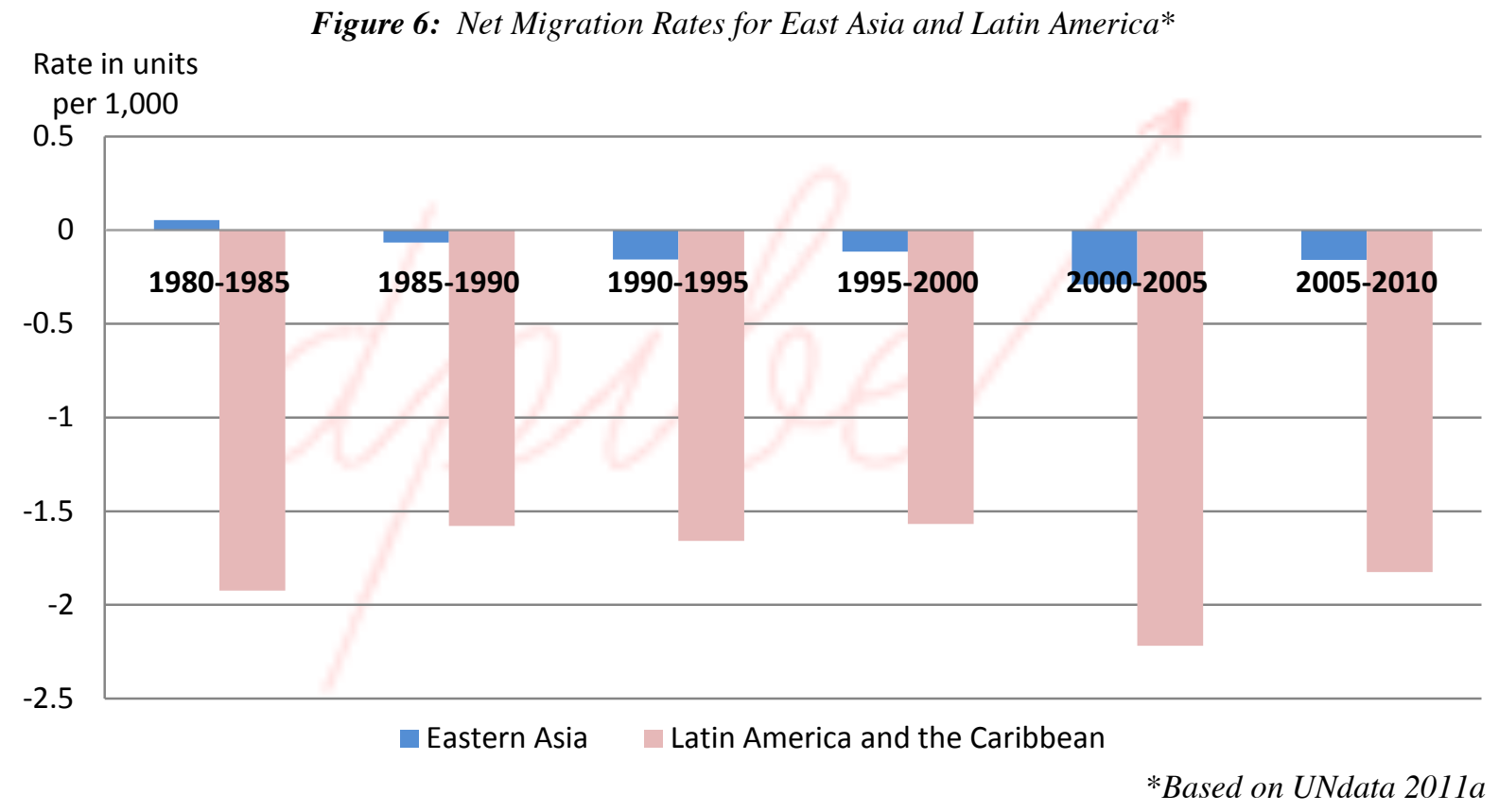


The impact of migration flows can be further appreciated by analysing the number of emigrants as a proportion of the originating region's total population. As at 2010, the total emigrants from East Asia represented 1.1 per cent of the entire East Asian population, whilst total emigrants from Latin America comprised 5.2 per cent (World Bank 2011d, pp. 23 and 27). Whilst the volume of net emigration is not itself definitive in establishing the cost of human capital flight, consideration of emigrant demographics can determine the proportion of tertiary educated emigrants that take their education with them (Rallu 2008). Thus, for every year of education an individual undertakes, the amount of public expenditure vested in that education will be greater, thereby exacerbating the loss to that economy if the individual emigrates.

Figure 7 highlights the migrant population fluctuations within Latin America and East Asia. Although regional totals for tertiary qualified emigrants are unavailable, the emigration rate of trained physicians proves somewhat effective in gauging the underlying rate. The data appears to demonstrate that the investment made in education for developing human capital is retained slightly more effectively in East Asia than it is in Latin America. Although emigration from Hong Kong and Singapore does stand out, it is alleviated by the much higher level of immigration. By comparison, Latin America demonstrates greater emigration than immigration in all sample countries. 
Figure 7: Migrant Population Fluctuations and the Emigration Rate of Tertiary Qualified Individuals*

\begin{tabular}{|c|c|c|c|c|c|}
\hline Region & Country & $\begin{array}{c}\text { Emigrants as a \% } \\
\text { of population }\end{array}$ & $\begin{array}{c}\text { Immigrants as a \% } \\
\text { of population }\end{array}$ & $\begin{array}{l}\text { Emigration rate of } \\
\text { physicians trained } \\
\text { in the region \% } \\
\end{array}$ & $\begin{array}{c}\begin{array}{c}\text { Emigration rate of } \\
\text { tertiary educated } \\
\text { population }\end{array} \\
\end{array}$ \\
\hline \multirow[t]{7}{*}{ East Asia } & Total region & $1.1 \%$ & $0.3 \%$ & $1.4 \%$ & ( $*$ \\
\hline & China & $0.6 \%$ & $0.1 \%$ & $0.2 \%$ & $3.8 \%$ \\
\hline & South Korea & $4.3 \%$ & $1.1 \%$ & $5.4 \%$ & $5.6 \%$ \\
\hline & Japan & $0.6 \%$ & $1.7 \%$ & $0.9 \%$ & $1.2 \%$ \\
\hline & Hong Kong & $10.2 \%$ & $38.8 \%$ & $30.4 \%$ & $28.8 \%$ \\
\hline & Indonesia & $1.1 \%$ & $0.1 \%$ & $1.4 \%$ & $2.1 \%$ \\
\hline & Singapore & $6.1 \%$ & $40.7 \%$ & $15.5 \%$ & $15.2 \%$ \\
\hline \multirow[t]{8}{*}{ LATAM } & Total region & $5.2 \%$ & $1.1 \%$ & $5.0 \%$ & $*$ \\
\hline & Argentina & $2.4 \%$ & $0.0 \%$ & $2.9 \%$ & $2.5 \%$ \\
\hline & Bolivia & $6.8 \%$ & $1.5 \%$ & $5.1 \%$ & $5.8 \%$ \\
\hline & Brazil & $0.7 \%$ & $0.4 \%$ & $0.6 \%$ & $2.2 \%$ \\
\hline & Chile & $3.7 \%$ & $1.9 \%$ & $5.1 \%$ & $6.1 \%$ \\
\hline & Colombia & $4.6 \%$ & $0.2 \%$ & $5.7 \%$ & $10.4 \%$ \\
\hline & Ecuador & $8.3 \%$ & $2.9 \%$ & $2.7 \%$ & $9.5 \%$ \\
\hline & Mexico & $10.7 \%$ & $0.7 \%$ & $8.5 \%$ & $15.3 \%$ \\
\hline
\end{tabular}

*Total region emigration of tertiary educated population is unavailable. As such, emigration of physicians can provide an indicative rate.

*Based on World Bank 2011d

This bias towards higher education emigration from Latin America is further indicated by Pellegrino (2002), who observes Mexico's unskilled or low skilled workers typically migrating to the United States, whilst South American unskilled workers may migrate intraregionally depending on availability within labour markets. It is generally the middle class in Latin America who will migrate to Europe, North America and Australia, draining the region of human capital and the public spending benefits of education (Pellegrino 2002). 


\section{CONCLUSION}

In considering the lack of economic growth experienced in Latin America, one cannot ignore the influence of education on the endogenous growth model. The quality of education has become indicative of the worth of a labour force, a key determinant in economic productivity. As such, if an economy covets economic prosperity, it must instil its people with both the desire and requisite knowledge to succeed in economic competition within the world arena.

Despite its financial and political efforts in educational reform, Latin America continually fails to replicate the East Asian formula for improving education in developing regions. Internationally standardised cognitive testing consistently shows Latin America at the lower end of the spectrum, whilst East Asia continues to enjoy its position at the higher end. Moreover, Latin America has a much greater negative migration rate than East Asia, including a higher proportion of tertiary qualified emigrants, restricting its ability to accumulate and maintain its own human capital.

What has become evident from this paper is that economic growth and success is predicated on the knowledge and skills of an effectively educated labour force. This is the key determinant that separates the economic growth of Latin America from East Asia. In essence, Latin America's failure lies largely with the quality of its labour, its human capital. Fortunately, with time and careful analysis of the education offered by more successful regions, Latin America will be able to reform, and finally experience sustained positive economic growth. 


\section{References}

Aghion, P \& Durlauf, S (2009). From Growth Theory to Policy Design, Commission on Growth and Development, retrieved 21 August 2011,

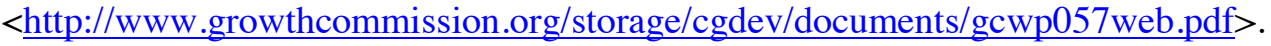

Barro, RJ \& Lee, J (2001). 'International data on educational attainment: Updates and implications', Oxford Economic Papers, vol. 53, no.3, pp. 541-563.

Baty, P (2010). 'Top 200 - The Times Higher Education World University Rankings 2010-2011', retrieved 22 August 2011, <http://www .timeshighereducation.co.uk/world-universityrankings/2010-2011/top-200.html>.

Birdsall, N (1999). Education: The People's Asset, Bangladesh Online Research Network, retrieved 21 August $2011,<$ http://www.bdresearch.org/home/attachments/article/448/education-the\%20people's\%20asset.pdf $>$.

CIA (2011). 'CIA - The World Fact Book - Country Comparison: Population', retrieved 22 August 2011, <https://www.cia.gov/library/publications/the-world-factbook/rankorder/2119rank.html>.

Cortright, J (2001). New Growth Theory, Technology and Learning: A Practitioner's Guide, U.S. Economic Development Administration, retrieved 21 August 2011, $<$ http://www.eda.gov/ImageCache/EDAPublic/documents/pdfdocs/1g31r_5f7_5fcortright_2epd f/v1/1g31r_5f7_5fcortright.pdf $>$.

Coulombe, S, Tremblay, JF \& Marchand, S (2004). International Adult Literacy Survey: Literacy Scores, Human Capital and Growth Across Fourteen OECD Countries, Statistics Canada and Human Resources and Skills Development Canada, retrieved 22 August 2011, $<$ http://www.statcan.gc.ca/pub/89-552-m/89-552-m2004011-eng.pdf $>$.

Hanushek, EA \& Kimko, DD (2000). 'Schooling, Labor Force Quality, and the Growth of Nations', American Economic Review, vol. 90, no. 5, pp. 1184-1208.

Hanushek, EA \& Woessmann, L (2009). Schooling, Cognitive Skills, and the Latin American Growth Puzzle, Stanford Center for International Development, retrieved 21 August 2011, $<$ http://scid.stanford.edu/system/files/shared/Hanushek_5-13-09.pdf $>$. 
Krueger, AB \& Lindahl, M (2001). 'Education for growth: Why and for whom?', Journal of Economic Literature, vol. 39, no.4, pp. 1101-1136.

OECD (2003). Literacy Skills for the World of Tomorrow: Further Results from PISA 2000, Organisation for Economic Co-operation and Development, retrieved 21 August 2011, $<$ http://www.oecd.org/dataoecd/43/9/33690591.pdf $>$.

OECD (2004). Learning for Tomorrow's World: First Results from PISA 2003, Organisation for Economic Co-operation and Development, retrieved 21 August 2011, $<$ http://www.oecd.org/dataoecd/1/60/34002216.pdf $>$.

OECD (2007). The Programme for International Student Assessment (PISA), Organisation for Economic Co-operation and Development, retrieved 21 August 2011, $<$ http://www.oecd.org/dataoecd/15/13/39725224.pdf $>$.

OECD (2010a). OECD Family Database - PF 1.2: Public Spending on Education, Organisation for Economic Co-operation and Development, retrieved 22 August 2011, $<$ http://www.oecd.org/dataoecd/45/48/37864432.pdf $>$.

OECD (2010b). PISA 2009 Results: Executive Summary, Organisation for Economic Co-operation and Development, retrieved 21 August 2011, $<$ http://www.oecd.org/dataoecd/34/60/46619703.pdf $>$.

Pellegrino, A (2002). Skilled Labour Migration from Developing Countries: Study on Argentina and Uruguay, International Labour Organisation, retrieved 22 August 2011, $<$ http://www.ilo.org/public/english/protection/migrant/download/imp/imp58e.pdf $>$.

Rallu, JL (2008). Population, Migration and Development in Asia, with Special Emphasis on the South Pacific: The Impact of Migration on Population and the MDGs, United Nations, retrieved 22 August 2011, $<$ http://www.un.org/esa/population/meetings/EGM_Ittmig_Asia/P02_Rallu.pdf> .

SCImago (2007). 'SJR - SCImago Journal \& Country Rank', retrieved 22 August 2011, $<$ http://www.scimagojr.com>. 
UNdata (2011a). 'UNdata I record view I Net migration rate', retrieved 22 August 2011, $<$ http://data.un.org/Data.aspx?d=PopDiv\&f=variableID\%3A85>.

UNdata (2011b). 'UNdata I record view I Public expenditure on education as \% of GDP', retrieved 22 August 2011, <http://data.un.org/Data.aspx?d=UNESCO\&f=series\%3AXGDP_FSGOV>.

World Bank (2011a). ‘GDP (current US\$) I Data I Table’, retrieved 22 October 2011, $<$ http://data.worldbank.org/indicator/NY.GDP.MKTP.CD>.

World Bank (2011b). 'GDP per capita (current US\$) I Data I Table', retrieved 22 October 2011, $<$ http://data.worldbank.org/indicator/NY.GDP.PCAP.CD $>$.

World Bank (2011c). 'GDP per capita growth (annual \%) I Data I Table', retrieved 22 October 2011, $<$ http://data.worldbank.org/indicator/NY.GDP.PCAP.KD.ZG $>$.

World Bank (2011d). Migration and Remittances Factbook 2011, $2^{\text {nd }}$ edn, The World Bank, retrieved 22 October 2011, <http://siteresources.worldbank.org/INTLAC/Resources/Factbook2011Ebook.pdf $>$. 